\title{
2-Phenylethylamine catabolism by Escherichia coli K-12: gene organization and expression
}

\author{
Steven P. Hanlon, † Terena K. Hill, Margaret A. Flavell, \\ Joseph M. Stringfellow and Ronald A. Cooper
}

Author for correspondence: Ronald A. Cooper. Tel: +44116 2523455 Fax: +441162523369.

Department of Biochemistry, University of Leicester, Leicester LE1 $7 \mathrm{RH}, \mathrm{UK}$

\begin{abstract}
A gene encoding phenylacetaldehyde dehydrogenase (PAD), the enzyme involved together with a copper-topaquinone-containing amine oxidase in the initial steps of 2-phenylethylamine catabolism, was located at $31.1 \mathrm{~min}$ on the Escherichia coli K-12 genetic map. It was immediately adjacent to the gene encoding the amine oxidase but transcribed in the opposite direction. The purified PAD acted almost equally well on phenylacetaldehyde, 4hydroxyphenylacetaldehyde and 3,4-dihydroxyphenylacetaldehyde. It had a subunit size of $54 \mathrm{kDa}$ and its deduced amino acid sequence was approximately $\mathbf{4 0} \%$ identical to various eukaryotic and prokaryotic aldehyde dehydrogenases. A third gene encoding a positive regulatory protein required for expression of the amine oxidase and PAD genes was located next to the PAD gene. A gene previously located in this position was reported to encode a second amine oxidase but this was not confirmed. The nucleotide sequence from 1447 to $1450 \mathrm{~kb}$ on the E. coli K-12 physical map has been determined.
\end{abstract}

Keywords: Escherichia coli, amine oxidase, aldehyde dehydrogenase, regulator gene

\section{INTRODUCTION}

We have previously described the reactions whereby Escherichia coli $\mathrm{K}-12$ converts 2 -phenylethylamine to phenylacetic acid through the sequential action of an amine oxidase and an aldehyde dehydrogenase (Parrott et al., 1987). The amine oxidase is of particular interest because it is a member of the copper-topaquinone family of amine oxidases (Cooper et al., 1992) whose organic co-factor is formed autocatalytically (Matsuzaki et al., 1994; Hanlon et al., 1995). Recently, a second amine oxidase gene was reported to be located very close to the gene encoding the 2-phenylethylamine oxidase (PEO) (Azakami et al., 1994).

To see whether this putative second amine oxidase also contained copper and topaquinone, we have studied the region of the E. coli K-12 genome adjacent to the PEO gene. Our results show that the region reported to encode the second amine oxidase actually encodes a

† Present address: University of Dundee, Biomedical Research Centre, Nine wells Hospital and Medical School, Dundee DD1 95Y, UK.

Abbreviation: PAD, phenylacetaldehyde dehydrogenase; PEO, 2-phenylethylamine oxidase.

The SWISS-PROT accession number for the phenylacetaldehyde dehydrogenase $\mathrm{N}$-terminal amino acid sequence reported in this paper is $\mathrm{P} 80668$. The GenBank/EMBL accession number for the nucleotide sequence reported in this paper is $X 99402$. regulatory protein that acts positively on the genes encoding PEO and phenylacetaldehyde dehydrogenase (PAD).

\section{METHODS}

Plasmids, bacterial strains and growth conditions. Plasmid pJPB13 carrying PstI fragment P41l (Bouché, 1982; Fig. 1) in pBR325 was kindly provided by Dr J. P. Bouché (CNRS, Toulouse, France). pUC18/19 (Norrander et al., 1983) were used as vectors for DNA cloning and expression with $E$. coli $\mathrm{K}-12$ strains $\mathrm{K} 10$ (Hfr PO2A pit-10 relA1 spoT1 tonA22 $\mathrm{T}_{2}^{\mathrm{R}}$; Bachmann, 1972) and JM109 ( $\mathrm{F}^{-}$recA1 supE44 endA1 bsdR17 gyrA96 relA1 thi $\Delta\left(\right.$ lac-proAB) $\left[\mathrm{F}^{\prime}\right.$ traD36, proAB lacl $\left.^{9} \mathrm{Z} \Delta \mathrm{M} 15\right]$; Yanisch-Perron et al., 1985) as hosts. E. coli strain C (CGSC $3121 ; \lambda^{-}$) was kindly provided by Dr B. J. Bachmann (CGSC, Yale University, USA). Cells were grown on M63 minimal medium (Miller, 1972) with $15 \mathrm{mM}$ succinate as carbon source and supplemented with ampicillin $(100 \mu \mathrm{g}$ $\left.\mathrm{ml}^{-1}\right)$. 2-Phenylethylamine $(5 \mathrm{mM})$ or IPTG $(0.5 \mathrm{mM})$ was incorporated as inducer as required.

Enzyme assays. Methods for the preparation of cell-free extracts and the continuous assay of amine oxidase (EC 1.4.3.6) by measurement of phenylacetaldehyde production and PAD (EC 1.2.1.39) by NADH formation were as described previously (Parrott et al., 1987). Protein was measured using the Folin reagent with bovine serum albumin as standard (Layne, 1957).

Purification of PAD. Succinate-grown JM109(pRC1948) cells $\left(100 \mathrm{ml}\right.$ culture) were harvested at $\operatorname{OD}_{680} 0.6$ by centrifugation 
Table 1. Purification of $P A D$

Details of the purification procedures are given in the text. One unit (U) of enzyme activity is defined as the amount of enzyme required to transform $1 \mu \mathrm{mol}$ substrate $(\mathrm{min})^{-1}$.

\begin{tabular}{|c|c|c|c|c|c|c|}
\hline Purification step & $\begin{array}{c}\text { Volume } \\
\text { (ml) }\end{array}$ & $\begin{array}{l}\text { Total } \\
\text { protein } \\
(\mathbf{m g})\end{array}$ & $\begin{array}{c}\text { Total } \\
\text { enzyme } \\
\text { (U) }\end{array}$ & 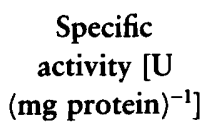 & $\begin{array}{c}\text { Recovery } \\
(\%)\end{array}$ & $\begin{array}{l}\text { Purification } \\
\text { (-fold) }\end{array}$ \\
\hline Ultracentrifuged crude extract & $3 \cdot 0$ & $8 \cdot 0$ & $28 \cdot 0$ & 3.5 & 100 & 1 \\
\hline Mono $Q$ peak fraction & $1 \cdot 0$ & $1 \cdot 2$ & $19 \cdot 4$ & $16 \cdot 2$ & 69 & $4 \cdot 6$ \\
\hline Phenyl-Superose peak fraction & $1 \cdot 0$ & $0 \cdot 3$ & $12 \cdot 2$ & $41 \cdot 0$ & 44 & $11 \cdot 7$ \\
\hline
\end{tabular}

at $10000 \mathrm{~g}$ for $5 \mathrm{~min}$ at $4{ }^{\circ} \mathrm{C}$ and the pellet resuspended in $4 \mathrm{ml}$ $20 \mathrm{mM}$ Tris/ $\mathrm{HCl}$ buffer, pH 6.8, containing $10 \%$ glycerol and $0.5 \mathrm{mM}$ DTT (extraction buffer). The cells were broken by $30 \mathrm{~s}$ treatment at $0^{\circ} \mathrm{C}$ in a MSE Soniprep 150 ultrasonicator operating at $10 \mu \mathrm{m}$ amplitude and the crude extract ultracentrifuged at $180000 \mathrm{~g}$ for $90 \mathrm{~min}$ at $4{ }^{\circ} \mathrm{C}$. For purification by FPLC at $22^{\circ} \mathrm{C}, 3.0 \mathrm{ml}$ supernatant $(8 \mathrm{mg}$ protein) was applied to a Mono Q HR 5/5 anion exchange column equilibrated with the extraction buffer. A $15 \mathrm{ml}$ gradient of $0-1 \cdot 0 \mathrm{M} \mathrm{NaCl}$ in extraction buffer at a flow rate of $1 \mathrm{ml} \mathrm{min}^{-1}$ was used as eluant and $1 \mathrm{ml}$ fractions collected. PAD was eluted at $0.25 \mathrm{M}$ $\mathrm{NaCl}$. The peak fraction was applied to a Phenyl-Superose HR 5/5 column equilibrated with extraction buffer containing $1 \mathrm{M} \mathrm{NaCl}$. The $\mathrm{NaCl}$ concentration was reduced to zero over

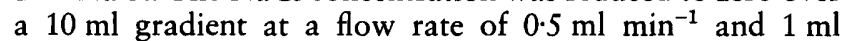
fractions collected. PAD was eluted after the end of the gradient. Details of the purification are given in Table 1.

Molecular mass estimations. Subunit molecular mass was estimated by SDS-PAGE (Laemmli, 1970) calibrated with bovine albumin $(66 \mathrm{kDa})$, egg albumin $(45 \mathrm{kDa})$, glyceraldehyde-3-phosphate dehydrogenase $(36 \mathrm{kDa})$, bovine carbonic anhydrase $(29 \mathrm{kDa})$, bovine pancreas trypsinogen $(24 \mathrm{kDa})$, soybean trypsin inhibitor $(20 \mathrm{kDa})$ and bovine milk $\alpha$-lactalbumin $(14 \cdot 2 \mathrm{kDa})$.

$\mathbf{N}$-terminal sequencing. The purified PAD was run on a 7.5-20\% SDS-polyacrylamide gel, then electroblotted onto a PVDF membrane (Matsudaira, 1987) using $50 \mathrm{mM}$ glycine/50 $\mathrm{mM}$ Tris, $\mathrm{pH} 10$, and stained with Coomassie brilliant blue $\mathrm{R}$ 250 . A portion of the stained $54 \mathrm{kDa}$ protein was excised and loaded into an Applied Biosystems 470A gas-phase sequencer without polybrene.

DNA manipulations. Small-scale plasmid preparations were carried out as described by Sambrook et al. (1989). Restriction endonucleases, calf intestinal phosphatase and T4 DNA ligase were used according to the manufacturer's instructions. DNA fragments were isolated from agarose gels using a JETsorb kit (GENOMED Inc., NC 277009-4526). Transformations were carried out using MOPS-RbCl (Kushner, 1978).

Nucleotide sequencing and oligodeoxyribonucleotide synthesis. Plasmid DNA was prepared using the Wizard kit (Promega). Sequencing of both DNA strands was carried out using a Sequenase version 2.0 kit (USB) employing, initially, the pUC18/19 forward and reverse primers. Sequences were extended by designing further ('walking') primers based on the already determined sequence. These oligodeoxyribonucleotide primers were made with an Applied Biosystems model 380B DNA synthesizer using cyanoethylphosphoramidite chemistry.

Biochemicals and chemicals. Restriction endonucleases, calf intestinal phosphatase and T4 DNA ligase were from
Pharmacia. $\quad\left[{ }^{35} \mathrm{~S}\right] \mathrm{dATP} \alpha \mathrm{S} \quad\left(1000 \mathrm{Ci} \quad \mathrm{mol}^{-1}\right)$ was from Amersham. 2-Phenylethylamine, tyramine (4-hydroxyphenylethylamine), dopamine (3,4-dihydroxyphenylethylamine) and phenylacetaldehyde were from Sigma. Solutions of phenylacetaldehyde, 4-hydroxyphenylacetaldehyde and 3,4dihydroxyphenylacetaldehyde (approximately $1 \mathrm{mM}$ ) were prepared from the corresponding amines, using amine oxidase from the periplasm fraction of JM109(pKC13) (Hanlon et al., 1995). The formation of aldehyde was monitored using PAD and on completion the reaction mixes were deproteinized by ultrafiltration. All other chemicals were of analytical grade.

Computer analysis. Comparisons of deduced amino acid sequences were made using the GAP program (Genetics Computer Group, 1991). International databases were searched using the basic local alignment search tool (BLAST) program (Altschul et al., 1990). The enzyme kinetic data were analysed via the Michaelis-Menten equation using a custom-written non-linear least squares-fitting algorithm.

\section{RESULTS AND DISCUSSION}

\section{Location of the PAD and PEO genes}

pJPB13 with a $9 \mathrm{~kb}$ Pst I fragment (Fig. 1) from 1445$1454 \mathrm{~kb}$ on the $E$. coli K-12 physical map (Berlyn et al., 1996) includes the gene for PEO (Hanlon et al., 1995). A $5 \mathrm{~kb}$ EcoRI $(1453.4 \mathrm{~kb})-P v u \mathrm{II}(1448.4 \mathrm{~kb})$ subclone in

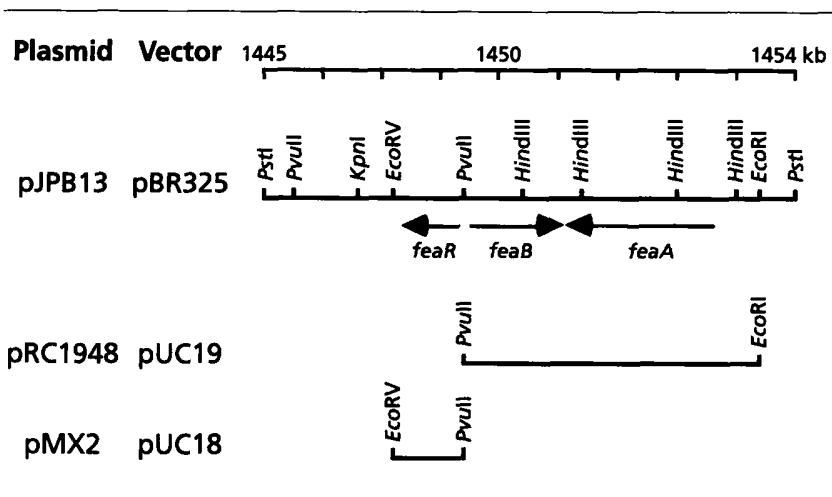

Fig. 1. Partial restriction site map of $\mathrm{pJPB} 13$ and derived subclones. Only the cloned DNA is shown. The scale gives the corresponding region of the $E$. coli K-12 physical map (Berlyn et al., 1996). The locations of the 2-phenylethylamine (fea) catabolic genes are shown, with an arrow indicating the direction of transcription; fea $R$ encodes the positively acting regulator involved in the expression of feaA (PEO) and feaB (PAD). 
pUC18 still expressed the amine oxidase gene in response to IPTG [specific activity $0.4 \mathrm{U}(\mathrm{mg} \text { protein })^{-1}$ ] but when the orientation with respect to the vector promoter was reversed by insertion into pUC19, the amine oxidase gene was barely expressed [specific activity $0.004 \mathrm{U}(\mathrm{mg}$ protein $\left.)^{-1}\right]$. This indicated that the direction of transcription of the amine oxidase gene was in the $E c o R I \rightarrow P v u I$ direction. When the same extracts were tested for PAD, the activity was barely detectable when pUC18 was the vector [specific activity $0.02 \mathrm{U}(\mathrm{mg}$ protein $)^{-1}$ ] but was present at very high activity for the pUC19-based construct [specific activity $3.2 \mathrm{U}$ (mg protein) ${ }^{-1}$ ]. This latter construct has been designated pRC1948 (Fig. 1). Thus this $5 \mathrm{~kb}$ fragment encoded both enzymes for conversion of 2-phenylethylamine to phenylacetic acid but apparently the two genes were transcribed in opposing directions.

\section{PAD N-terminal amino acid sequence and activity against related compounds}

The NAD-dependent PAD purified 10-fold from JM109(pRC1948) showed a single band on SDS-PAGE that corresponded to a molecular mass of $54 \mathrm{kDa}$ and was at least $95 \%$ pure. The $\mathrm{N}$-terminal sequence of this $54 \mathrm{kDa}$ protein was found to be: Met-Thr-Glu-Pro-HisVal-Ala-Val-Leu.

The purified enzyme reacted readily with either phenylacetaldehyde, 4-hydroxyphenylacetaldehyde or 3,4dihydroxyphenylacetaldehyde as co-substrate, but all showed inhibition at concentrations over $10 \mu \mathrm{M}$, as noted previously for PAD from Achromobacter eurydice (Fujioka et al., 1970). At aldehyde concentrations around $10 \mu \mathrm{M}$, needed to determine $K_{\mathrm{m}}$ and $V_{\text {max }}$ values, the allowable $A_{340}$ changes were very small and consequently the experimental error was quite high. The kinetic values were measured using five aldehyde concentrations over the range $2-20 \mu \mathrm{M}$ at $275 \mu \mathrm{M}$ NAD. The $K_{\mathrm{m}}$ and $V_{\max }$ values, with standard errors, representative of results seen from three separate experiments were $7 \pm 1 \mu \mathrm{M}$ and $38 \pm 2 \mathrm{U}$ (mg protein) ${ }^{-1}$ for phenylacetaldehyde; $4 \pm 1 \mu \bar{M}$ and $50 \pm 2 U$ (mg protein) ${ }^{-1}$ for 4hydroxyphenylacetaldehyde; and $6 \pm 1 \mu \mathrm{M}$ and $32 \pm 2 \mathrm{U}$ (mg protein) $^{-1}$ for 3,4-dihydroxyphenylacetaldehyde, respectively.

\section{Nucleotide sequence determination}

Nucleotide sequence from both ends of the $5 \mathrm{~kb}$ insert DNA of pRC1948 was determined to confirm the direction of transcription of the amine oxidase and aldehyde dehydrogenase genes. The amine oxidase gene (maoA) has been sequenced (Azakami et al., 1994; Parsons et al., 1995) and we located the $5^{\prime}$ end of this sequence at the EcoRI end of the insert DNA (data not shown). Nucleotide sequence starting $130 \mathrm{bp}$ from the PvuII site gave translated amino acid sequence that matched exactly the protein $\mathrm{N}$-terminal amino acid sequence reported in the preceding section. This identification of the $5^{\prime}$ end of the PAD gene confirms the direction of transcription suggested from the expression studies. The stem-loop system proposed to act as a transcription terminator for the maoA gene was $1611 \mathrm{bp}$ from the PvuII site, close to the putative end of the PAD gene. It is possible that this same system, on the opposite strand, also serves as a transcription terminator for the PAD gene.

The amino acid translation of the PAD-encoding gene was compared to the databases using the BLAST procedure (Altschul et al., 1990). The evolutionary relatedness of many NAD $(P)$-linked aldehyde dehydrogenases has been documented (Hempel et al., 1993) and the significant amino acid sequence identity (35-40\%) found between PAD and very many such aldehyde dehydrogenases from a variety of prokaryotic and eukaryotic sources indicated that it too was a member of that family of proteins. Surprisingly, $359 \mathrm{bp}$ of the nucleotide sequence, which is downstream of the maoA gene, was identical to part of the untranslated sequence reported by Azakami et al. (1994) to be upstream of the maoA gene, with the match ending at a HindIII site (1449.4 kb, Fig. 1). The amino acid translation of this matching region also showed strong identity with various $\mathrm{NAD}(\mathrm{P})$-linked aldehyde dehydrogenases.

\section{Identification of the putative second amine oxidase gene as a regulatory gene}

It had been claimed that a gene encoding a second amine oxidase was located close to the amine-oxidaseencoding maoA (Azakami et al., 1994). To investigate this claim the EcoRV $(1447 \cdot 2 \mathrm{~kb})-P v u \mathrm{II}(1448.4 \mathrm{~kb})$ region of pJPB13 was subcloned into the $S m a$ I site of pUC18. JM109 with one such construct, pMX1, showed at least fourfold higher amine oxidase activity than JM109(pUC18). 2-Phenylethylamine caused a 20-fold increase in amine oxidase activity but IPTG had no effect (Table 2). A second construct, pMX2 (Fig. 1), with the insert DNA in the opposite orientation to that of pMX1 also showed a 20-fold increase in amine oxidase activity in response to 2-phenylethylamine. However, for pMX2, IPTG now led to a 30-fold increase in amine oxidase activity. IPTG had no effect on amine oxidase production by JM109(pUC18). These results suggested that in pMX2 a gene responsible for increased amine oxidase activity was transcribed in the same direction as the pUC18 lac promoter.

The nucleotide sequence of the $1.2 \mathrm{~kb}$ EcoRV-PvuII region, which is immediately adjacent to the region encoding the PAD gene, was determined. This sequence showed unique $\mathrm{NcoI}$ and SnaBI restriction endonuclease sites located centrally within the cloned DNA. These were used to create a 219 bp deletion by digesting pMX2 with the two endonucleases, filling in the Ncol sticky ends and religating the DNA. This new construct, designated pMX2D, no longer led to expression of the amine oxidase in JM109 on induction with IPTG, indicating that the gene responsible had been disrupted.

Analysis of the nucleotide sequence revealed an ORF of $903 \mathrm{bp}$ and the deduced amino acid sequence of this putative gene showed no significant identity with any 
Table 2. Influence of various plasmids on amine oxidase and PAD activities produced by E. coli K-12 strains JM109 and K10

Cells were grown at $30^{\circ} \mathrm{C}$ on succinate minimal medium with ampicillin and induced for two to three cell doublings. Specific activities [U (mg protein $)^{-1}$ ] are representative values from a minimum of three separate estimations. Plasmids are described in the text. ND, not determined.

\begin{tabular}{|c|c|c|c|c|c|c|}
\hline \multirow[t]{3}{*}{ Host strain } & \multirow[t]{3}{*}{ Inducer } & \multicolumn{5}{|c|}{ Specific activity [U (mg protein $\left.)^{-1}\right]$} \\
\hline & & \multicolumn{3}{|c|}{ Amine oxidase } & \multicolumn{2}{|c|}{ PAD } \\
\hline & & pUC18 & $\mathrm{pMX1}$ & pMX2 & pUC18 & pMX2 \\
\hline JM109 & None & $<0.001$ & 0.004 & 0.004 & ND & ND \\
\hline JM109 & IPTG & $<0.001$ & 0.003 & $0 \cdot 125$ & ND & ND \\
\hline JM109 & Phenylethylamine & 0.003 & 0.075 & 0.083 & ND & ND \\
\hline K10 & None & $<0.001$ & ND & 0.470 & $<0.001$ & $0 \cdot 320$ \\
\hline K10 & IPTG & $<0.001$ & ND & 0.420 & $<0.001$ & 0.330 \\
\hline
\end{tabular}
FeaR-Ec
249 RLDFCADAIRHA. ADDEKLAGIGFHWGFSDQSHFSTVFKQRFGMTPGEYRRKFR . . . . . .
XY1S-Pp 284 KLESIRACLNDPSANVRSITEIALDYGFLHLGRFAENYRSAFGELPSDTLRQCKKEVA......
RhaR-EC 259 RVCHAQYLLQHSRL . . .LISDISTECGFEDSNYFSVVFTRETGMTPSQWRHLNSQKD .......
RhaS-EC 224 RLMKARHLLRHSEA. . . SVTDIAYRCGFSDSNHFSTLFRREFNWSP . . RDIRQGRDGFLQ . . .
AYAC-EC 231 RISQAKLLLSTTRM. . . PIATVGRNVOFDDQLYTSRVFKKCTGASPSEFRAGCEEKVNDVAVKLS
MelR-EC 244 RINHVRALLSDTDK. . . SILDIALTAGFRSSSRFYSTFGKYVGMSPQQYRKLSQQRRQTFPG...

\begin{abstract}
Fig. 2. C-terminal amino acid sequence comparison for FeaR. The C-terminal region of the 2-phenylethylamine catabolism regulatory protein (FeaR) was matched with a selection of regulatory proteins from the AraCXXlS family. The fully conserved residues are shown in bold. The numbers indicate the residue of these approximately 300 residue proteins at which the sequence comparison starts. The alignment was carried out using the PILEUP program (Genetics Computer Group, 1991) with Gap Weight 3.0 and Gap Length Weight 0.1 settings. The sequence accession numbers are: FeaR, EMBL/GenBank X99402; XyIS, SWISS-PROT P07859; RhaR, SWISS-PROT P09378; RhaS, SWISS-PROT P09377; AraC, SWISSPROT P03021; MelR, SWISS-PROT P10411. Ec, E. coli; Pp, Pseudomonas putida.
\end{abstract}

amine oxidase sequence in the databases. However, there was some identity at its C-terminal end with members of the AraC/XylS class of transcriptional activators (Gallegos et al., 1993) as shown in Fig. 2.

\section{Nature of the amine oxidase elicited by pMX2 and identity of the encoded gene}

The amine oxidase produced by JM109(pMX2) was purified from the periplasmic fraction, as described previously (Cooper et al., 1992). The protein obtained was greater than $95 \%$ pure, as judged by SDS-PAGE, corresponded to a protein of molecular mass $80 \mathrm{kDa}$ and was a quinoprotein, as measured by the redox cycling staining method (Paz et al., 1991).

Its $\mathrm{N}$-terminal amino acid sequence was found to be His-Gly-Gly-Glu-Ala-His-Met-Val-Pro-Met which is identical to the product of the maoA gene (Azakami et al., 1994). Since a protein of $80 \mathrm{kDa}$ could not be encoded on a $1.2 \mathrm{~kb}$ piece of DNA that apparently was responsible for its production and its $10 \mathrm{~N}$-terminal amino acids were identical to those of PEO, it seemed that the PvuII-EcoRV fragment did not itself encode an amine oxidase but carried a regulatory gene whose product acted positively on PEO gene expression.
Further support for this view was obtained by use of $E$. coli strain $\mathrm{C}$ as host for $\mathrm{pMX}$. This bacterium lacks the $m a o A$ gene (R. A. Cooper, unpublished observation) and extracts prepared from $E$. coli $\mathrm{C}(\mathrm{pMX} 2)$ had no detectable amine oxidase activity.

\section{Control of PAD gene expression}

Both the amine oxidase and the aldehyde dehydrogenase were formed inducibly in E. coli K-12 strain K10 (Parrott et al., 1987). It seemed likely, therefore, that the regulatory protein that elicited amine oxidase production would also control formation of PAD. To test this possibility pMX2 was introduced into $E$. coli $\mathrm{K} 10$ and PAD and amine oxidase activities measured. Table 2 shows that both enzymes were present at high activities in uninduced cells and were not increased significantly by growth in the presence of IPTG. However, strain K10 with pUC18 displayed no detectable amine oxidase or PAD activities, even for cells induced with IPTG (Table 2). This indicates that the regulatory gene product was necessary for expression of the PAD gene. The apparent constitutive expression elicited by pMX2 in strain K10 is explained by the fact that $\mathrm{K} 10$ carries the normal lacl gene whose product would be unable to interact effectively with the regu- 
latory regions of all the copies of the pMX2 plasmid, thereby leading to constitutive production of the regulatory gene product due to expression via the thus unregulated lac promoter.

\section{Gene symbol}

The gene symbol mao (monoamine oxidase) that has been used for the PEO gene (Azakami et al., 1994) is inappropriate for the PAD gene which is the second component of the $E$. coli $\mathrm{K}-12$ system for conversion of 2-phenylethylamine to phenylacetic acid. Accordingly, we propose the gene symbol fea for 2-phenylethyl $a$ mine catabolism (pea is not available) with the PEO gene being feaA, the PAD gene being $f e a B$ and the regulatory gene being feaR. These three genes are located on the E. coli K-12 physical map between the EcoRV site at coordinate $1447 \mathrm{~kb}$ and the HindIII site at coordinate $1453 \mathrm{~kb}$ (Kohara et al., 1987). This position corresponds to $31 \cdot 1-31 \cdot 2 \mathrm{~min}$ on the E. coli $\mathrm{K}-12$ genetic map (Berlyn et al., 1996).

\section{Conclusions}

E. coli $\mathrm{K}-12$ can use phenylacetic acid but not 3- or 4hydroxyphenylacetic acid as carbon and energy source, whereas some other strains can grow on both aromatic acids (Burlingame \& Chapman, 1983). A direct consequence of this for $E$. coli $\mathrm{K}-12$ is that compounds such as 2-phenylethylamine that are converted to phenylacetic acid (Parrott et al., 1987) can serve as growth substrate but compounds such as tyramine that are converted to 4hydroxyphenylacetic acid cannot. However, since the amine oxidase and aldehyde dehydrogenase that are needed for growth on 2-phenylethylamine also convert tyramine to 4-hydroxyphenylacetic acid (Parrott $e$ t al., 1987), tyramine can serve as nitrogen source for growth of E. coli K-12. Because of their interest in tyramine catabolism by Klebsiella aerogenes, Murooka and colleagues, in studying the aromatic amine oxidase of E. coli $\mathrm{K}-12$, have used tyramine rather than 2phenylethylamine as inducer and substrate (Yamashita et al., 1993). Although they stated that the precise role of the monoamine oxidase in E. coli is unknown, it has been demonstrated previously by mutant analysis that it is required for growth on 2-phenylethylamine (Parrott $e t$ al., 1987) and presumably also for use of tyramine as nitrogen source. In most, if not all, situations concerning their initial degradation, 2-phenylethylamine and tyramine can be considered to be identical, so the results reported here focusing on 2-phenylethylamine can be compared directly with those of Murooka and colleagues employing tyramine.

What is described here on the identification of the putative second amine oxidase as a regulator gene is in agreement with the very recent revision of their claim (Yamashita et al., 1996). We also, importantly, show that the regulatory protein controls expression of the PAD gene. However, some differences between these two reports remain to be resolved. For instance, Yamashita et al. (1996) concluded that both the regu- latory protein and an aromatic amine (tyramine) were necessary for expression of the amine oxidase gene, whereas our results with pMX2 showed that the regulator gene induced by IPTG resulted in higher amine oxidase activity than when 2-phenylethylamine was the inducer. Hence, it seemed that only the regulator gene product was needed for amine oxidase gene expression.

The sequence of the regulator gene described by Yamashita et al. (1996) was identical to that which we report here. It is not known whether the K-12 strain, W3110, the source of the DNA they analysed, has a PAD gene but the finding of some sequence upstream of the amine oxidase gene (Azakami et al., 1994) matching part of the PAD gene was unexpected.

\section{ACKNOWLEDGEMENTS}

We are indebted to Dr K. S. Lilley and Ms E. Cavanagh for amino acid sequencing, Mrs D. Langton for oligodeoxyribonucleotide synthesis and Ms U. Gervind-Richards for producing the manuscript. We thank the Wellcome Trust for support via grant number $035179 / 1.5$.

\section{REFERENCES}

Altschul, S. F., Gish, W., Miller, W., Myers, E. W. \& Lipman, D. J. (1990). Basic local alignment search tool. J Mol Biol 215, 403-410.

Azakami, H., Yamashita, M., Roh, J.-H., Suzuki, H., Kumagii, H. \& Murooka, Y. (1994). Nucleotide sequence of the gene for monoamine oxidase (maoA) from Escherichia coli. J Ferment Bioeng 77, 315-319.

Bachmann, B. J. (1972). Pedigrees of some mutant strains of Escherichia coli K-12. Bacteriol Rev 36, 525-557.

Berlyn, M. K. B., Brooks Low, K. \& Rudd, K. E. (1996). Linkage map of Escherichia coli K-12, Edition 9. In Escherichia coli and Salmonella: Cellular and Molecular Biology, 2nd edn, pp. 1715-1902. Edited by F. C. Neidhardt, R. Curtiss III, J. L. Ingraham, E. C. C. Lin, K. Brooks Low, B. Magasanik, W. S. Reznikoff, M. Riley, M. Schaechter \& H. E. Umbarger. Washington, DC: American Society for Microbiology.

Bouché, J. P. (1982). Physical map of a $470 \times 10^{3}$ base-pair region flanking the terminus of DNA replication in the Escherichia coli K12 genome. J Mol Biol 154, 1-20.

Burlingame, R. \& Chapman, P. J. (1983). Catabolism of phenylpropionic acid and its 3-hydroxy derivative by Escherichia coli. J Bacteriol 155, 113-121.

Cooper, R. A., Knowles, P. F., Brown, D. E., McGuire, M. A. \& Dooley, D. M. (1992). Evidence for copper and 3,4,6trihydroxyphenylalanine quinone cofactors in an amine oxidase from the Gram-negative bacterium Escherichia coli K-12. Biochem J 288, 337-340.

Fujioka, M., Morino, Y. \& Wada, H. (1970). Phenylacetaldehyde dehydrogenase from Achromobacter eurydice. Methods Enzymol 17A, 593-596.

Gallegos, M.-T., Michán, C. \& Ramos, J. L. (1993). The XylS/AraC family of regulators. Nucleic Acids Res 21, 807-810.

Genetics Computer Group (1991). Program manual for the GCG package, version 7, Madison, Wisconsin.

Hanlon, S. P., Carpenter, K., Hassan, A. \& Cooper, R. A. (1995). Formation in vitro of the 3,4,6-trihydroxyphenylalanine quinone cofactor. Biochem J 306, 627-630.

Hempel, J., Nicholas, H. \& Lindahl, R. (1993). Aldehyde dehydro- 
genases: widespread structural and functional diversity within a shared framework. Protein Sci 2, 1890-1900.

Kushner, S. R. (1978). An improved method for the transformation of Escherichia coli with ColE1-derived plasmids. In Genetic Engineering, pp. 17-23. Edited by H. B. Boyer \& S. Nicosia. Amsterdam: Elsevier.

Laemmli, U. K. (1970). Cleavage of structural proteins during the assembly of the head of bacteriophage T4. Nature 227, 680-685.

Layne, E. (1957). Spectrometric and turbidimetric methods for measuring proteins. Methods Enzymol 3, 447-454.

Matsudaira, P. (1987). Sequence from picomole quantities of proteins electroblotted onto polyvinylidene difluoride membranes. J Biol Chem 262, 10035-10038.

Matsuzaki, R., Fukui, T., Sato, H., Ozaki, Y. \& Tanizawa, K. (1994). Generation of the topaquinone cofactor in bacterial monoamine oxidase by cupric ion-dependent autooxidation of a specific tyrosyl residue. FEBS Lett 351, 360-364.

Miller, J. H. (1972). Experiments in Molecular Genetics. Cold Spring Harbor, NY: Cold Spring Harbor Laboratory.

Norrander, J., Kempe, T. \& Messing, J. (1983). Construction of improved M13 vectors using oligonucleotide-directed mutagenesis. Gene 26, 101-106.

Parrott, S., Jones, S. \& Cooper, R. A. (1987). 2-Phenylethylamine catabolism by Escherichia coli K12. J Gen Microbiol 133, 347-351.
Parsons, M. R., Convery, M. A., Wilmot, C. M., Yadav, K. D. S., Blakeley, V., Corner, A. S., Phillips, S. E. V., McPherson, M. J. \& Knowles, P. F. (1995). Crystal structure of a quinoenzyme: copper amine oxidase of Escherichia coli at $2 \AA$ resolution. Structure 3, 1171-1184.

Paz, M. A., Fluckiger, R., Boak, A., Kagan, H. M. \& Gallop, P. M. (1991). Specific detection of quinoproteins by redox cycling staining. J Biol Chem 266, 689-692.

Sambrook, J., Fritsch, E. F. \& Maniatis, T. (1989). Molecular Cloning : a Laboratory Manual, 2nd edn. Cold Spring Harbor, NY: Cold Spring Harbor Laboratory.

Yamashita, M., Sakaue, M., Iwata, N., Sugino, H. \& Murooka, Y. (1993). Purification and characterization of monoamine oxidase from Klebsiella aerogenes. J Ferment Bioeng 76, 289-295.

Yamashita, M., Azakami, H., Yokoro, N., Roh, J. H., Suzuki, H., Kumagai, H. \& Murooka, Y. (1996). maoB, a gene that encodes a positive regulator of the monoamine oxidase gene $(m a o A)$ in Escherichia coli. J Bacteriol 178, 2941-2947.

Yanisch-Perron, C., Vieira, J. \& Messing, J. (1985). Improved M13 phage cloning vectors and host strains: nucleotide sequences of the M13mp18 and pUC19 vectors. Gene 33, 103-119.

Received 25 July 1996; revised 22 September 1996; accepted 26 September 1996. 